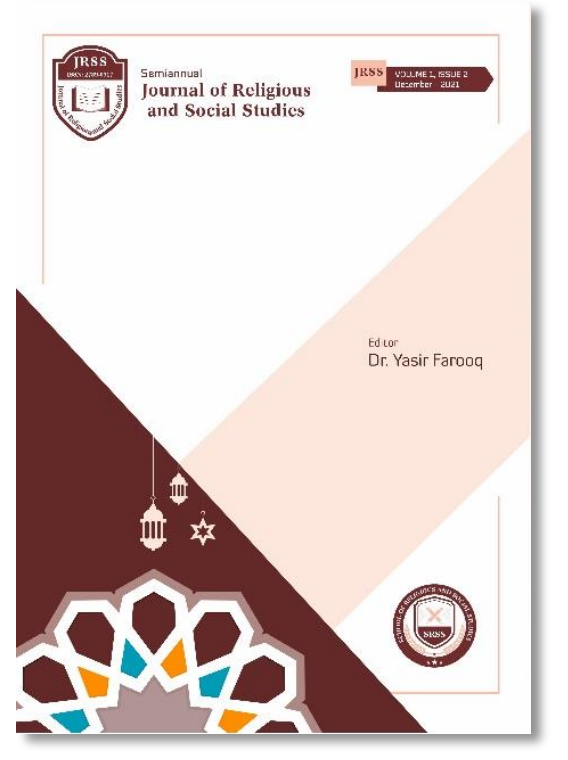

\title{
Journal of Religious and Social Studies
}

\author{
http://ejrss.com/index.php/jrss
}

ISSN (Print): 2789-0317

ISSN (online): 2789-0325

School of Religious and Social Studies,

Faisalabad (38000), Pakistan.

\section{Challenging Grand Narrative through Little Narrative: An Analysis of Fatima Mernissi's Perspectives}

Muhammad Salman Qazi, and Riaz Ahmad Saeed

To cite this article:

Muhammad Salamn Qazi, and Riaz Ahmad Saeed. "Challenging Grand Narrative through Little Narrative: An Analysis of Fatima Mernissi's Perspectives." Journal of Religious and Social Studies 1, no. 2 (2021): 51-64.

DOI: https:// doi.org/10.53583/jrss05.0102.2021

Published online: 30 September 2021

氙 Submit your article to JRSS

: View this issue

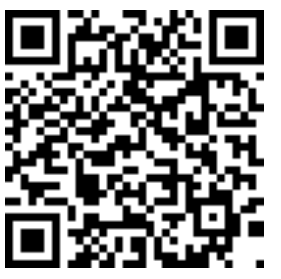

OPEN ACCESS

Full Terms \& Conditions of access and licensing can be found at: http://ejrss.com/index.php/jrss/policies

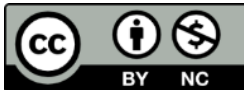




\title{
CHALLENGING GRAND NARRATIVE THROUGH LITTLE NARRATIVE: AN ANALYSIS OF FATIMA MERNISSI'S PERSPECTIVES
}

\author{
Muhammad Salman Qazi ${ }^{1}$, Riaz Ahmad Saeed ${ }^{2}$
}

\begin{abstract}
In this post-modern world, intellectuals and visionary scholars putting together Little Narratives on a tactical basis for challenging the Grand Narrative. Most recently, religious identification has taken the status of political grand narrative in post-colonial Arab Countries. Social, economic, military, and political failures have galvanized, progressive religious responses to western domination and globalization. Feminism and especially Islamic Feminism, playing its role as a little narrative for challenging the grand narrative of religious authoritarianism. This paper will focus on the work and ideas of Moroccan thinker, Fatima Mernissi in the theoretical framework of Carool Krestan's Progressive Category. In this paper, the Analytical, critical and comparative research methodology will be adopted with the qualitative research paradigm.
\end{abstract}

Keywords: Feminism, Feminist, Movement, Grand Narrative, Little Narrative, Fatima Mernissi, Carool Kersten.

\section{PRELUDE}

As a progressive thinker, Mernissi focused her ideas on the social status of women. She concentrated on the Tradition of the Holy Prophet (PBUH) and even doubted and questioned the authority and authenticity of the Ahadith. She declared Hadith as hostile towards women and called it "A tradition of Misogyny". Mernissi worked from a social scientific perspective on the issues of women. According to Mernissi, the tradition of the Holy Prophet (PBUH) has been misused by the political, social, and religious institutions

1 Department of English, International Islamic University, Islamabad, Pakistan.

2 Department of Islamic Studies, National University of Modern Languages, Islamabad, Pakistan. 
and authorities for the purpose to fabricate the existing equalities between men and women. This was the reason conservative Muslim critics perceived her earlier writing as a propagating tool for secularism. Mernissi with a unique style questioned the authority and authenticity of Hadith by comparing it with Qur'ān and ultimately rejected the traditional interpretation of the Qur'anic text.

\section{BIOGRAPHICAL SKETCH OF FATIMA MERNISSI}

In 1940, a little girl was born in a middle-class family in the Moroccan city of Fez, who was named Fatema Mernissi. She received her primary education at a school established by Nationalist Movement named Qur'ānic School while for secondary education she attended All-Girls School, which was run and funded by the French Protectorate. In 1965, she received a higher education degree at Muhammad $V$ University in Rabat in political science. She continued her education and received a Ph.D. degree under the dissertation topic The Effects of Modernization on the Male-Female Dynamics in a Muslim Society in sociology at Brandeis University in Massachusetts, USA. Between 1974 and 1981 she taught various subjects like family sociology, methodology, and psychosociology at Muhammad V University. At the Moroccan Institute Universitaire de Recherche Scientifique, Mernissi worked as researcher.

Following in the footsteps of earlier male advocates for women's rights in Morocco is Fatima Mernissi, one of the contemporary initiators of what is now called 'Islamic feminism'. Mernissi is widely considered a pioneer of Muslim feminist scholarship. ${ }^{3}$ In the 1990s, scholars such as Leila Ahmed, Fatima Mernissi, and Amina Wadüd instigated a new trajectory of thought that implicated early Muslim societies and contemporary Muslim practice in the decline of Muslim women's status. ${ }^{4}$

3 Doris H. Gray, Beyound Feminism and Islamism Gender and Quailty In North Africa (London: I.B Turis \& Co.LTD, 2015), 21.

4 Seedat Fatima, 'Islam, Feminism, and Islamic Feminism: Between Inadequacy and Inevitability', Journal of Feminist Studies in Religion 29, no. 2 (2013): 25-45. 


\section{FATIMA MERNISSI'S CONTRIBUTION: MAIN THEMES IN}

\section{CONNECTION TO THE CONTEMPORARY MUSLIM THOUGHT}

The discourse on gender is probably one of the most divisive and controversial in Morocco. Not a week goes by that issues related to women are not discussed in the media, at one academic conference or another, in a mosque, in parliament, or on the street. ${ }^{5}$ Since the 1970s in Morroco, Fatima Mernissi has written extensive work-related feminism. ${ }^{6}$ Mernissi presents the progressive-regressive movements concerning women's emancipation in Muslim society. ${ }^{7}$ Fatima Mernissi applied the method of contextualization in the interpretation of the Qur'ann and explains critically the rights, responsibility, authority, and position of women from an Islamic perspective. She has constructed contemporary Islamic thought based on a 'historical reading' and 'contextual reading' of the text. ${ }^{8}$

Among her renowned work, Beyond the Veil: Male-Female Dynamics in Modern Muslim Society was the first book of Mernissi published in 1975 by Schenkman. This book became a marvelous approach in the field of anthropology and sociology of women in the Arab world in particular and Muslim society in general, which was based on her Ph.D. theses.

Since it made Moroccan women aware of their bodies and sexuality, such a book had a significant influence on the rise of female consciousness among them. It aided in the transition of female identities in the sense that it sparked a progressive criticism of Arab Muslim society's assertions and beliefs on gender by breaking down such contentious topics as female fertility and racial discrimination in modern Islamic communities. ${ }^{9} \mathrm{Al}$ Saqi (1985) published a revised edition of this book with the introduction of Fatima Mernissi. In this boo western stereotypes have been challenged by her who were shared

$5 \quad$ Gray, Beyound Feminism and Islamism Gender and Quailty In North Africa, 31.

6 Nina Nurmila, 'The Influence of Global Muslim Feminism on Indonesian Muslim Feminist Discourse', Al-Jami'ah 49, no. 1 (2011): 44.

7 Ayesha Jalal, 'The Convenience of Subservience: Women and the State of Pakistan', in Women Islam and State (London: Palgrave Macmillan, 1991), 77-114.

$8 \quad$ MD. Yousuf Ali, 'A Contextual Approach to the Views of Muslim Feminist Interpretation of the Qur'ān Regarding Women and Their Rights', International Journal of Arts and Sciences 13, no. 3 (2010): 313-31.

$9 \quad$ Hanane El. Aissi, 'Moroccan Women's Writings: Rethinking Their Female Body and Sexuality', Journal of International Women's Studies 21, no. 2 (2020): 53-66. 
by European feminists as well. She argued that western representation of Islam served to de-legitimate the cultural categories and cognitive elements that shaped the lives of Arab women. ${ }^{10}$

Her second book LE MAROC RACONTÉ PAR SES FEMMES was published in 1983, of which revised edition was re-published in 1991 under the title PAROLÉS DES FEMMES DU MAROC. Meanwhile, in 1988 in Britain and 1989 in the USA, this book was translated into English and published under the title of DOING DAILY BATTLE. This book was based on interviews about the personal experiences of Moroccan women of different ages and different social classes.

Mernissi has no problem claiming feminism for herself and Islam. ${ }^{11}$ The abovementioned two books give us the vivid picture that Mernissi was a staunch Islamic feminist. She was deeply concerned with Islam and the role of women in the creation of a "Civic Society". She gives the feminist interpretation of Islam, that's why she can be considered the founder of 'Islamic Feminism'. Her two books, LE HAREM POLITIQUE (1987) and SULTANES OUBLIÉES (1990) are worth mentioning in the field of Islamic feminism and the role of women. The former was translated into English in 1991 as THE VEIL AND THE MALE ELITE: A Feminist Interpretation of Women's Rights in Islam in the USA. (The British publisher called it WOMEN AND ISLAM: An Historical and Theological Enquiry). The role of women in the spread and articulation of Islam has been highlighted by this book. The women's rights in Islam and the tackling argument of Mernissi, that the main root of patriarchy is that Shari'ah has been mutilated by men, and women have never had the chance to interpret it in a gender-sensitive context. ${ }^{12}$ She further, laments women's rights and roles in contemporary Muslim society, which she sketches to some early Islamic scholars who distorted the texts of the Qur'ān and AHadith were fabricated by them. ${ }^{13}$

10 Fatima Marnissi, Beyond the Veil: Male-Female Dynamics in Modern Muslim Society (Cambridge, Massachusetts: Schenkman Publication Co, 1975).

11 Fatima, 'Islam, Feminism, and Islamic Feminism: Between Inadequacy and Inevitability', 36.

12 Fatima Marnissi, Women and Islam-An Historical and Theological Inquiry, trans. Mary Jo Lakeland (New Dehli: Kali for Women, Women Unlimited, 2004).

13 Ali, 'A Contextual Approach to the Views of Muslim Feminist Interpretation of the Qur'ān Regarding Women and Their Rights', 318. 
THE VEIL AND THE MALE ELITE were initially banned in Morocco. SULTANAS OUBLIÉES was published in an English translation in 1993 under the title THE FORGOTTEN QUEENS OF ISLAM. These two books are historically remarkable in scope. SULTANAS OUBLIÉES thematically about prophet Muhammad (PBUH) and LE HAREM POLITIQUE was about the political role of women, especially of those whose sovereignty was officially recognized. Her book, LA PEUR MODERNITÉ: Conflit Islam Démocratie, translated into English in 1993 as ISLAM AND DEMOCRACY: Fear of the Modern World was published in 1992, which can be called the Muslim historiography. In this book, she discusses the historical information of the post-Gulf war and the Muslim world. All this information encompasses the question of democracy, political power, and civil society of the Muslim world. To subvert the democratic process through despots' use of Islamic symbolism has been revealed by Mernissi in this book. Moreover, the religion was seen by her as a symbolic recourse that subverts the legitimate democratic set up by the people. ${ }^{14}$ In The Forgotten Queens of Islam, the power and agency of the queens in the Islamic world have been highlighted. She thinks that political authority in the Islamic world was never an exclusively male prerogative.

Political authority is also exercised by women but unfortunately has been erased from history. ${ }^{15}$

Mernissi wrote an autobiographical style novel, DREAMS OF TRESPASS (or THE HAREM WITHIN in the UK edition) which received noteworthy appreciation from the world and was published in 28 countries with translation. Through her fiction style, she grabbed the attention of a global audience. Mernissi published various articles and essays about women and Islam in various journals. She contributed through her articles in Signs: Journal of Women in Culture and Society, Women's Studies International Forum, and Feminist Issues. She also contributed to the anthology SISTERHOOD IS GLOBAL, edited by the American feminist activist Robin Morgan (1984), in which she gave the picture of women in Morocco. Statistical information of 70 countries is provided alphabetically in this anthology.

14 Fatima Marnissi, Islam and Democracy: Fear of the Modern World, trans. Mary Jo Lakeland (New York: Addison-Wolsey Publishing Co, 1992).

15 Fatima Marnissi, The Forgotten Queens of Islam (Minneapolis: University of Minnesota, 1997). 
Interestingly, almost all the books of Mernissi have been published by European and American academics, but in Muslim countries, some feminist organizations also published her work. In Pakistan for example, the socialist-feminist ASR Resource Centre for Women, set up in 1983, published a version of FORGOTTEN QUEENS OF ISLAM, while Editions le Fennec published a French version in 1990, as well as French and Arabic versions of several other books. Mernissi describes Layla Chaouni, the long-time Publisher of Editions le Fennec in Casablanca, as 'committed to the struggle for human rights' and notes her help in the production of books and collections from local research collectives.

In final words, Mernissi through her writings made global fans and audience, and on issues such as Islam and women, women's situation in the Muslim world, development, democracy, civil society building, globalization, North African immigration to Europe, and world literature she became as a visiting scholar, participating in numerous international, regional, or national conferences. Fatima Mernissi produced many great works for which she received many awards and appreciation. Among all, the Prince of Asturias Award (Spain) 2003 such as the Prince of Asturias Award is worth mentioning. It is her distinction that her book Beyond the Veil: Male-Female Dynamics in Modern Muslim Society is translated into more than 30 languages. Similarly, Dreams of Trespass: Tales of A Harem Girlhood was translated is translated in more than 25 languages. The other works of Fatima Mernissi are; L'amour Dans les pays musulmans in 1984; Femmes du Gharb in 1985; Le harem politique in 1987; Shahrazad n'est pas marocaine in 1988 (rev. 1992); Sultanes oubliées in 1990; La Peur-Modernité in 1992; Women's Rebellion and Islamic Memory in 1993; Les Aït-Débrouille in 1997; Etes-vous vaccine contre le Harem? in 1998; Scheherazade Goes West in 2001, Beyond the Veil, Male-Female Dynamics in Muslim Society (1976), Woman in the Muslim Unconscious (1984) under the pseudonym Fatna A. Sabbah, Veil and the Male Elite - A Feminist Interpretation of Women's Rights in Islam (1987), Islam and Democracy, Fear of the Modern World (1993), Dreams of Trespass, Tales of a Harem Girlhood (1994), The Forgotten Queens of Islam (1997), and Scheherazade Goes West: Different Cultures, Different Harems (2002) are the benchmarkers about women and status of women in Islam. On November 30, 2015, she died in Rabat. 


\section{CRITIQUES OF MERNISSI}

Fatima Mernissi is one of the Muslim feminist scholars who attempt to reinterpret the Qur'ānic verses. Fatima Mernissi, offers something new, "identifying gender terms used in the Qur' $\bar{a} n^{\prime \prime} .{ }^{16}$ Fatima Mernissi gave a new direction to issues of gender in Islam by contextualizing methodology. However, through this innovative approach, she catches the critical eyes of the critics. Among her critics, are the key figures. Both these critics complain of her unsympathetic position toward Islam. In the opinion of Hatem, a reductionist approach towards the reading of the Qur'a $n$ has been adopted by Mernissi, which results in the ambiguity and plurality of meaning. Hatem, on the other hand, explains his idea that "Mernissi approaches Muslim texts and their discourses without an adequate appreciation of their ambiguous character. She views Muslim discourses as having 'an almost mathematical logic' in which ambiguities are foreign".

Another name in the list of Mernissi's critiques is, who thinks that Islam is taken by Mernissi as the religion of inequality of gender and propagator of patriarchy. She further elaborates her opinion that;

"Thus, one of the most prominent Muslim feminists can claim that Islam is a patriarchal and even misogynistic religion that "professes models of hierarchical relationships and sexual inequality and puts a sacred stamp [onto] female subservience." These are the words of Fatima Mernissi and she's certainly not alone in holding such views. Muslim feminists almost universally consider Islam misogynistic because they view God "himself" as being oppressive. Because many Muslim feminists don't believe in the divine, they do not find it meaningful to engage the Qur'an or even to read it. But this doesn't keep some of them from making false claims about it. ${ }^{17}$

Contributions to Secular and Islamic feminism discourse are indispensable, as she opined, "the evolution of feminism from a movement premised on the rejection of the status quo to one of accommodation and reform." ${ }^{18}$ Within the Islamic framework,

16 Nurmila, 'The Influence of Global Muslim Feminism on Indonesian Muslim Feminist Discourse', 55-56. Asma Barlas, Believing Women in Islam: Unread Patriarchal Interpretations of the Qur'ān (Texas: University of Texas Press, 2019), 11. 
Mernissi also received harsh criticism. Lamia Ben Youssef Zayzafoon in Production of the Muslim Woman argues;

"Mernissi reproduces the Islamist originality narrative locating the origin of culture and civilization in the early years of Islam."19

Barlow and Akbarzadeh analyzed the opinion of Zayzafoon in their work by stating;

"Reinforcement of those traditional patterns of authority that is undeniably patriarchal, antidemocratic and unrepresentative." 20

Furthermore, another renowned Moroccan anthropologist, Naima Chikhaoui critiqued Mernissi by pointing out that, "Mernissi's second-stage [Islamic] feminism [is] 'soft,' in contrast to her earlier more radical secular feminism." 21

There are also some critiques, who try to defend the ideas of Mernissi through their writings. The top name in her defender critiques is, who defend Mernissi since her earlier works like Beyond the Veil (1975) and The Veil and the Male Elite (1987) show her as a feminist of radical sensibility. About Mernissi and her work, she says that;

"Mernissi's work 'transcends the disciplinary boundaries of sociology, the initial domain of her academic formation and incorporates the closed domain of religion and experiments with fiction." 22

Mernissi was categorized by Rhouni as 'Woman in the Muslim Unconscious' and compared her to the secular feminist Fatna Aid Sabbah who re-wrote the Moroccan history from the female perspective. The demarcation was done by her in works of seculars because political and civil actors of colonialism, nationalism, and the postcolonial state, as well as Marxism, feminism and their roles in forming the 'Moroccan woman', was the main target of Mernissi". ${ }^{23}$ In the opinion of Rhouni that L'Amour Dans les pays musulmans, The Veil and the Male Elite, and Islam and Democracy is the

\footnotetext{
19 Raja Rhouni, Secular and Islamic Feminist Critiques in the Work of Fatima, Mernissi (Netherlands: Leiden: Brill, 2010), 3.

$20 \quad$ Ibdi., 5 .

21 Ibid.

22 Ibid., 39.

23 Ibid., 40.
} 
incorporation of both secular and Islamic feminist sentiments. She ultimately argues that Mernissi begins to form a "new theoretical path that bridges the two approaches." ${ }^{24}$

\section{CRITICAL ASSESSMENT OF MERNISSI'S THOUGHTS IN THE CONNECTION TO THE CATEGORIES DEFINED BY CAROOL KERSTEN}

By engaging critically, the ideas presented by Mernissi in her work critically, the researcher concluded that Fatima Mernissi is neither Traditional nor Reaction rather she is a Progressive Islamic thinker. These three categories have been identified by Carool Kresten in his book 'Contemporary Muslim Thought in the Muslim World'. By critical analysis of the works of contemporary Muslim thinkers, we can put them at any of these three categories on the account of their ideas.

\section{MERNISSI AND PROGRESSIVE ISLAMIC DISCOURSE}

According to Carool, progressive thinkers are those "who are operating in the interstices between different cultural traditions, the resulting liminality of their positions has stimulated on intellectual creativity from which they have developed novel ways of engaging with the Islamic tradition, arriving at innovating interpretation of the intellectual heritage of the Muslim world through the methodological lenses of the humanities and social sciences. These thinkers are widely read and acknowledged". ${ }^{25}$

Mernissi's interpretation of the verses, for instance, depends directly on a certain understanding of its occasions of revelation, while the Qur'an gives some indications of the dates of the surah. Muslim scholars' methods of dating surah focus on the Hadith and the biography of the prophet Mohammad (PBUH). However, the historical validity of this literature used by Mernissi is questionable. ${ }^{26}$

24 Raja Rhouni, Secular and Islamic Feminist Critiques in the Work of Fatima, Mernissi, 39.

25 Kersten Carool, Contemporary Thought in the Muslim World: Trends, Themes, and Issues (England: Routlege, 2019).

26 Ali, 'A Contextual Approach to the Views of Muslim Feminist Interpretation of the Qur'ān Regarding Women and Their Rights', 327. 
This progressive Islamic discourse can successfully be applied to Fatima Mernissi. Her approach towards Islam and women is from a unique perspective, even she doubts some of the Hadith, and by giving opinion that they are male-dominated.

\section{ANALYSIS OF MERNISSI'S THOUGHT AND VIEWS:}

Mernissi counts that to shield women of higher social class, ladies' slaves were forfeited. Women were annoyed on the roads and were encouraged to submit the demonstration of adultery. Also, as Prophet couldn't do much about it, Prophet guaranteed the security of his spouses and different Muslims in a city. At the point when Prophet requested the examination of the circumstance from the individuals who were acting thusly. They said, "We just practice ta'arrud with women we accept to be slaves" and they pardoned themselves by saying that they were confounded about the character of the ladies towards whom they moved.

Mernissi finds that, through an overwhelmingly male interpretation of Islamic law since its founding, many commentators now regard Islam and Islamic law as sexist, although these attitudes are not supported by Islamic legal texts. ${ }^{27}$ By critical analysis of Mernissi's work, we can conclude that she is a progressive Muslim thinker. Eradication of public/private distinction and access to public life was the main concern of Mernissi and she made a distinction between religion as personal belief and religion as law. Muhammad (PBUH) and his companions in contemporary discourse on the rights of women were stressed by her.

On the other hand, Mernissi is not without her critics. Conservative Muslim scholars are both critical and dismissive of Mernissi's reinterpretation of the Hadith. Progressive Muslims engaged in other reform projects have also criticized Mernissi. ${ }^{28}$ Her writing provides evidence to substantiate the claim that 'women passivity, seclusion and their marginal place in Muslim society had nothing to do with Muslim tradition and was, on the contrary, a contemporary ideological production.

27 John Hursh, 'Advancing Women's Rights through Islamic Law: The Example of Morocco', Berkeley J. Gender L. E Just 27 (2012): 252. 


\section{FATIMA MERNISSI AND ḤADĪTH: A PROGRESSIVE ISLAMIC THINKER}

Fatima Mernissi is among the contemporary Muslim feminist who questioned the authenticity and authority of Hadith. During the middle ages, numerous scholars discussed the issue of authority and authenticity of the Hadith. Ibn Khaldun (1332-1406) was one of few scholars who addressed the subject of Hadith authority in his Muqaddimah (1967). Contemporary Muslim scholars and leaders, from Muhammad 'Abduh ([18491930] 1964), to Zaynab Fawwaz ([1860-1914] her letters of 1892 cited in Belhachmi, 2008), Mahmood Muhammad Taha (1987), Jamal al Banna (2005, 2008), Kacia Ali (2006, 2010), Jonathan Brown (2009), Muhammad Shahrur (2009), Asma Sayeed (2013), and Ziba MirHosseini (2013) discussed this issue that how 'some' Hadīth are contradictory to Qur'ān. ${ }^{29}$

Mernissi's strategy is basically to criticize the interpreters of Islam, but not Islam. ${ }^{30}$ Mernissi through her writings opined that the tradition of the Prophet (PBUH) has been misused by political, social, and religious institutions for the purpose to fabricate the existing inequalities between men and women. She expresses her opinion in her first book, Beyond the Veil, in the following words;

"Paradoxically, and contrary to what is commonly assumed, Islam does not advance the thesis of women's inherent inferiority. Quite the contrary, it affirms the potential equality between the sexes." She goes on the existing inequality ...is the outcome of specific social institutions designed to restrain her woman's power" ${ }^{\prime \prime 3}$

This was the reason conservative Muslim critics perceived her earlier writings as propagating toll for secularism. Mernissi with a unique style questioned the authority and authenticity of Hadith by comparing it with Qur'ann. In this way, she rejected the traditional interpretation of the Qur'ann's text. She states:

29 Nimat Hafez Barazangi, 'Fatema Mernissi and the Hadith: Agent of Social Change' (at the 50th Middle East Studies Association Annual Meeting, Panel \# P4374, Boston, Massachusetts, 17 November 2016).

30 Hursh, 'Advancing Women's Rights through Islamic Law: The Example of Morocco', 292.

31 Fatima Marnissi, Beyond the Veil: Male-Female Dynamics in Modern Muslim Society, vol. 423 (Indiana: Indiana University Press, 1987), 19. 
"Hadith emerged as a formidable political weapon," elaborating further on the historical backgrounds of such misogynistic narratives in her book Women and Islam"32

This statement was the bashing point for her critiques. Mernissi challenges patriarchal assertions within the Hadith much in the same way that she reinterprets the Qur'ān. Mernissi's reinterpretation of the Hadith challenges traditional Islamic Scholars within their discourse. ${ }^{33}$

\section{MERNISSI'S CONCEPT OF HAREEM: DILEMMA OF TRADITIONAL VS PROGRESSIVE (MODERN)}

In her novel, Dreams of Trespass: Tales of A Harem Girlhood the contrast values related to women's life within harem between the traditional and modern has been discussed by Mernissi. Through this novel, she narrated the proper behavior, activities, and thoughts, and desires of women. These all are the main focused discussion between modern and traditional debates. Of women's rights. Mernissi presented her ideas through the characters of her novel for example, for the modern view as like Fatima's mother, Yasmina, and aunt Habibah harem is like a prisoned place. Harem restricts women from their dream to get education, knowledge, and wide society.

The Issue relates to women's freedom and emancipation. On other hand, the traditional side views that their tradition is really hard to change. They have to respect and love their culture and they have to show their identity by wear and behave as their own culture teaches them

From Lalla Mani and Lalla Radia perspective, harem is wonderful place, Harem was formed by men, so women do not have to gout into dangerous and unsafe streets (war situation) they get safety and luxury for their happiness.

Fatima Marnissi, The Veil and the Male Elite: A Feminist Interpretation of Women's Rights in
Islam, trans. Mary Jo Lakeland (Boston: Addison-Wolsey Publishing Co, n.d.).
Hursh, 'Advancing Women's Rights through Islamic Law: The Example of Morocco', 294. 


\section{CONCLUSION}

By critical analysis of Mernissi's work, we can successfully conclude that she is a 'Progressive Muslim Thinker'. The concept of the traditional way of thinking about women and women's status and thinking about her status in the contemporary world is clearly and successfully demonstrated in her novel, Dreams of Trespass: Tales of A Harem Girlhood. Eradication of public/private distinction and access to public life was the main concern of Mernissi. A clear distinction between religion as a personal belief and religion as the law was made by her. Women's autonomy as an endogenous phenomenon was her life's best victory. Holy Prophet Muhammad (PBUH) and his companions in the contemporary discourse on the rights of women were stressed by her. According to her, the historical sources themselves provided enough material to substantiate a claim that 'women's passivity, seclusion and their marginal place in Muslim society had nothing to do with Muslim tradition and was, on the contrary, a contemporary ideological production. 
Journal of Religious and Social Studies

December-2021, Vol.: 1, Issue: 2, PP: 51-64

https://doi.org/10.53583/jrss05.0102.2021

\section{BIBLIOGRAPHY}

Aissi, Hanane El. 'Moroccan Women's Writings: Rethinking Their Female Body and Sexuality'. Journal of International Women's Studies 21, no. 2 (2020): 53-66.

Ali, MD. Yousuf. 'A Contextual Approach to the Views of Muslim Feminist Interpretation of the Qur'ān Regarding Women and Their Rights'. International Journal of Arts and Sciences 13, no. 3 (2010): 313-31.

Barazangi, Nimat Hafez. 'Fatema Mernissi and the Hadith: Agent of Social Change'. Presented at the at the 50th Middle East Studies Association Annual Meeting, Panel \# P4374, Boston, Massachusetts, 17 November 2016.

Barlas, Asma. Believing Women in Islam: Unread Patriarchal Interpretations of the Qur'ān. Texas: University of Texas Press, 2019.

Barlow, Rabecca, and Shahram Akbarzadeh. 'Women's Rights in the Muslim World: Reform or Reconstruction?"'. Third World Quarterly 27, no. 8 (2006): 1481-94.

Carool, Kersten. Contemporary Thought in the Muslim World: Trends, Themes, and Issues. England: Routlege, 2019.

Fatima, Seedat. 'Islam, Feminism, and Islamic Feminism: Between Inadequacy and Inevitability'. Journal of Feminist Studies in Religion 29, no. 2 (2013): 25-45.

Gray, Doris H. Beyound Feminism and Islamism Gender and Quailty In North Africa. London: I.B Turis \& Co.LTD, 2015.

Hursh, John. 'Advancing Women's Rights through Islamic Law: The Example of Morocco'. Berkeley J. Gender L. \& Just 27 (2012): 252-306.

Jalal, Ayesha. 'The Convenience of Subservience: Women and the State of Pakistan'. In Women Islam and State, 77-114. London: Palgrave Macmillan, 1991.

Marnissi, Fatima. Beyond the Veil: Male-Female Dynamics in Modern Muslim Society. Cambridge, Massachusetts: Schenkman Publication Co, 1975.

- - - Beyond the Veil: Male-Female Dynamics in Modern Muslim Society. Vol. 423. Indiana: Indiana University Press, 1987.

- - - Islam and Democracy: Fear of the Modern World. Translated by Mary Jo Lakeland. New York: Addison-Wolsey Publishing Co, 1992.

- - - . The Forgotten Queens of Islam. Minneapolis: University of Minnesota, 1997.

- - - . The Veil and the Male Elite: A Feminist Interpretation of Women's Rights in Islam. Translated by Mary Jo Lakeland. Boston: Addison-Wolsey Publishing Co, n.d.

- - - Women and Islam-An Historical and Theological Inquiry. Translated by Mary Jo Lakeland. New Dehli: Kali for Women,Women Unlimited, 2004.

Nurmila, Nina. 'The Influence of Global Muslim Feminism on Indonesian Muslim Feminist Discourse'. Al-Jami'ah 49, no. 1 (2011): 44.

Rouni, Raja. Secular and Islamic Feminist Critiques in the Work of Fatima, Mernissi. Netherlands: Leiden: Brill, 2010. 